\title{
Profile Analysis of Mathematical Problem Solving Abilities with Krulik \& Rudnick Stages Judging from Medium Visual Representation
}

\author{
Iva Desi Ruliani ${ }^{1 *}$, Nizaruddin ${ }^{2}$, Yanuar Hery Murtianto ${ }^{3}$ \\ ${ }^{1}$ Pendidikan Matematika, Universitas PGRI Semarang. Sidodadi Timur Street No. 24, \\ Semarang 50232, Indonesia. \\ *Email : yanuarherymurtianto@gmail.com
}

Article received : 23-01-2018, article revised : 28-08-2018, article published: 07-09-2018

DOI : $10.25273 /$ jipm.v7i1.2123

\begin{abstract}
The ability to solve mathematical problems is very important in learning math and everyday life. According to Krulik \& Rudnick there are 5 stages of problem solving that is Read, Explore, Select A Strategy, Solve And Look Back. Mathematical problems require multiple representational skills to communicate problems, one of which is visual representation. Trigonometry is one of the materials that uses visual representation. This research is a qualitative descriptive research that aims to describe the ability of problem solving mathematics with Krulik \& Rudnick stages in terms of visual representation. The study was conducted in MAN 2 Brebes. Determination of Subjects in this study using Purposive Sampling. Research instruments used to obtain the required data are visual representation and problem-solving tests, and interview guidelines. The data obtained were analyzed based on the Krulik \& Rudnick problem solving indicator. Subjects in this study were subjects with moderate visual representation. Based on the results, problem solving ability of the subject is not fully fulfilled. Subjects with visual representations are able to do problem solving well that is solving the problem through a concept that is understood without visualization of the image. Subjects with visual representations are having a schematic visual representation type.
\end{abstract}

Keywords : Problem Solving; Krulik \& Rudnick Stages; Visual Representation.

\section{INTRODUCTION}

Problems are things that students definitely encounter in learning. One important aspect that needs to be known by the teacher in the success of a learning is to know the students' ability to solve a problem.

One of the subjects taught in schools in the education curriculum is mathematics. Mathematics is a subject that is still considered difficult by students. Complaints and disappointments towards the results achieved by students in mathematics are still often expressed and in general students say mathematics is a difficult and tedious lesson because it has to deal with formulas that are difficult to remember in solving mathematical problems (Nawi, 2012 : 82). It shows that students still feel difficulties in solving mathematical problems because they are still fixated in mathematical formulas. Based on preliminary studies conducted by researchers that the material in mathematics learning in schools which is still considered difficult by students is trigonometry. In line with the results of research conducted by Listiyana (2012) shows that students tend to have difficulties in communicating what is known and asked about trigonometric problems. The problems raised in this study prove that students need to improve the ability to communicate everything that is known and asked by connecting the knowledge that was previously owned to solve the problem.

The ability of students to communicate something in problem solving is called representation ability (Sabirin, 2014 : 33). 
Furthermore, Sabirin explained that the representation abilities possessed by students can make problems that originally seemed difficult and complicated to be easier and simpler. Representation is very instrumental in mathematics, namely to simplify problems and solve problems (Mulyati, 2016). Besides that, representation is also useful to help students make mathematical ideas more concrete (Rezeki, 2017). Mathematical learning should further enhance the ability of mathematical representation in order to easily solve mathematical problems. Students should also improve their ability to solve math problems in the form of problem solving given because the current curriculum requires students to solve more complicated problems, therefore students must also improve their abilities in problem solving. Complicated in this case are questions that students have never found before. Mathematical problems that are considered complicated require solutions to solve them.

Krulik and Rudnick define problem solving as follows: Problem solving is a process. It is the means by which an individual uses previously acquired knowledge, skills, and understanding to satisfy the demands of an unfamiliar situation (Krulik \& Rudnick, 1988). that problem solving is a process. Furthermore, Krulik and Rudnick explained that problem solving is a means of an individual who uses prior knowledge, skills and understanding to meet the demands of unusual circumstances. This shows that problems that have never been found make students go through a long process to get a solution where students must use the knowledge, skills and understanding that have been obtained previously.
Mathematics is one of the fields of science that can form critical, creative, logical and systematic thinking patterns, as well as the ability to use mathematics in problem solving (Rosanti, Rizal, \& Ismaimuza, t.t.). The mindset that is formed is inseparable from positive habits that are always carried out by students such as practicing solving mathematical problems. The problems in mathematics learning can be in the form of math problems that require students to use some of their representational abilities. The ability of representation can be classified into three, namely 1) visual representations (pictures, diagrams, graphs, or tables), 2) symbolic representations (mathematical statements / mathematical notations, numerical / algebraic symbols), and 3) verbal representations (written texts) (Gordah \& Fadillah, 2014). As with trigonometry material, the representation ability developed by students one of them is visual representation.

Hudiono's research (2010) states that students' mathematical representation ability is still low. The low ability of mathematical representation is mainly visual representation because students tend to be difficult to represent mathematics subjects into graphs, pictures, or diagrams because students tend to use the left brain rather than the right brain.

The solution that can be used is to know in advance how the steps or stages of students in solving a problem. There were three experts who formulated the problem solving stages namely John Dewey, George Polya and Krulik \& Rudnick. Carson (2007) presents the stages of problem solving according to the three experts in the table 1 below:

Table 1. Stages of Problem Solving According to the Three Experts

\begin{tabular}{l|l|l|l}
\hline \multirow{2}{*}{$\begin{array}{l}\text { steps problem } \\
\text { solving }\end{array}$} & \multicolumn{1}{|c|}{ John Dewey (1933) } & \multicolumn{1}{|c}{ George Polya (1988) } & Krulik \& Rudnick (1980) \\
\cline { 2 - 4 } & Confront Problem & Understanding the problem & Read \\
\cline { 2 - 4 } & Diagnose or Define Problem & & Explore \\
\cline { 2 - 4 } & Inventory Several Solutions & Devising a plan & Select A Strategy \\
\cline { 2 - 4 } & Test Consequences & Carrying out the plan & Solve \\
\cline { 2 - 4 } & & looking back & Look Back \\
\hline
\end{tabular}

Source : (Carson) 


\section{JIPM (Jurnal Ilmiah Pendidikan Matematika), 7(1), September 2018 - 24}

Iva Desi Ruliani, Nizaruddin, Yanuar Hery Murtianto

The difference in the three stages of problem solving can be seen in table 1 . In this study the problem solving stages used are the Krulik \& Rudnick solving stages. At the Krulik \& Rudnick stage, it is different from the other two stages, there are five stages. The five stages in table 1 show that the Krulik \& Rudnick stages unite both Dewey and Polya's problem solving stages, in addition to the more detailed and coherent stages. The stages of problem solving proposed by Krulik \& Rudnick, (1988) are: (1) read, (2) explore (3), select a strategy, (4) solve , and (5) Look Back. After knowing the stages or steps of students in problem solving, then a solution can be found to solve mathematical problems by using the ability of visual representation possessed by students in trigonometric materials.

Hegarty \& Kozhevnikov (1999) states that there are two types of visual representations related to student success in solving mathematical problems, namely (a) pictorial representations (pictures), visual displays of the objects described, and (b) schematic representations (schemes), describe spatial relationships. Based on this description, the selection of students with visual representations is being associated with the type of visual representation mentioned by Hegarty \& Kohzenikov as follows on the table 2 below:

Table 2. Visual Representation Type Indicators

\begin{tabular}{cll}
\hline $\begin{array}{c}\text { Visual } \\
\text { Representation }\end{array}$ & \multicolumn{1}{c}{$\begin{array}{c}\text { Indicator according to Hegarty } \boldsymbol{E} \\
\text { Kohzenikov }\end{array}$} & \multicolumn{1}{c}{ Explanation } \\
\hline Schematic & $\begin{array}{l}\text { the student drew a diagram, used } \\
\text { gestures showing the spatial relations } \\
\text { between objects in a problem in } \\
\text { explaining their solution strategy, or } \\
\text { reported a spatial image of the } \\
\text { relations expressed in the problem. }\end{array}$ & $\begin{array}{l}\text { - } \\
\begin{array}{l}\text { Describe a diagram / use cues that show } \\
\text { spatial relationships between objects in a } \\
\text { problem in explaining the solution strategy, } \\
\text { or describe the spatial image of the } \\
\text { relationship stated in the problem. }\end{array}\end{array}$ \\
\hline Pictorial & $\begin{array}{l}\text { the student reported an image of the } \\
\text { objects or persons referred to in a } \\
\text { problem, rather than the relations } \\
\text { between these objects. }\end{array}$ & $\begin{array}{l}\text { Describe the object or person referred to in a } \\
\text { problem, and not the relationship between } \\
\text { these objects. }\end{array}$ \\
\hline
\end{tabular}

Source : (Hegarty \& Kozhevnikov)

Table 2 explains that the type of pictorial visual representation is different from the schematic, which is to describe the object image in the problem. Whereas in trigonometry subjects, more visual representations are needed to communicate students' understanding of questions with image objects and also require other mathematical skills.

Based on the description, the purpose of this article is to find out and describe from each stage the profile of students' problem solving abilities based on the medium visual representations that students have. After the problem solving is known at each stage, the writer also analyzes the type of visual representation of the subject.

\section{METHOD}

This research is a qualitative descriptive study. This research was conducted in MAN
2 Brebes, in the even semester of 2016/2017 school year. Subjects in this study were one student of class X MIPA 4 MAN 2 Brebes who had moderate representation abilities. Determination of research subjects using purposive sampling. To determine students with moderate visual representation abilities, students from class X MIPA 4 were asked to complete visual representation test questions, then the researcher analyzed the results of visual representation tests using a visual representation indicator, the test was conducted on May 22, 2017. In this study the data obtained were problem solving tests on trigonometric material from the subject and interview transcripts of researchers with research subjects. Test problem solving ability test instrument given to research subjects in the form of questions on trigonometric material with answer sheets made according 
to the problem solving stages of Krulik \& Rudnick. The implementation of data collection with tests of mathematical problem solving skills and interviews was conducted for two days, namely on May 24 and 26, 2017. The data in this study were collected directly by researchers, so the main instrument in this study was the researcher himself.

Data analysis techniques in this study using the Miles \& Huberman model which consists of 3 stages (Agustinova, 2015), namely:

1. Data reduction stage

a. Correcting student work results from visual representation tests which are then grouped into high, medium and low based on visual representation indicators.

b. After being grouped, from each group one student was taken to be the subject of the research for further problem solving tests.

c. Studying student work results and making initial notes to be used as interview material, raw data is transformed into notes as material for interviews.

d. Arrange the results of interviews with good language then processed into data that is ready for use.

2. Data presentation stage (data display),

The data presented in the form of student work results, data from interviews and the results of the analysis of students' problem solving abilities of each research subject which is the findings data. Findings data in the form of mathematical problem solving abilities based on visual representations of each subject and analyzing the type of visual representation that is owned by the subject.

\section{Stage of conclusions (conclusion drawing/ verification)}

In this study, verification is done by comparing the results of students 'work in problem solving tests and the results of interviews and then can be concluded how students' mathematical problem solving skills. The researcher also identifies the type of visual representation that is owned by the subject based on the results of the analysis of tests and interviews.

The results of the analysis of the written test data and interview data were reviewed to get valid data. Triangulation that is used using triangulation method is by comparing the results of the written test results and data from the interview. Valid data is used to determine the mathematical problem solving ability of the subject.

\section{RESULTS AND DISCUSSION}

The research subject was determined based on the results of the visual representation test on class X MIPA 4 MAN 2 Brebes. The visual representation test results are analyzed based on the visual representation indicator that has been determined by the researcher and then grouping based on a low visual representation of $8.57 \%$, medium $28.57 \%$ and height of $62.85 \%$ (figure 1). Here are the results of groupings based on visual representation:

\section{Representasi Visual}

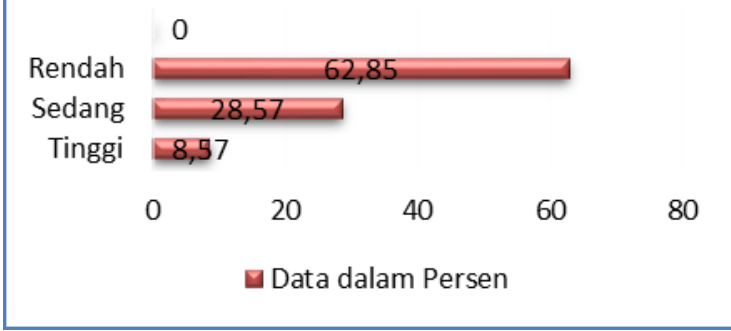

Figure 1. Visual Representation Grouping Graph

In the figure, it is stated that students with moderate visual representation amount to $28.57 \%$. As explained in the introduction, the researcher determined subjects with purposive sampling technique and determined the research subject was a subject with moderate visual representation ability because in this study aims to see students' mathematical problem solving abilities based on visual representations owned by students, students chosen with medium representation because based Preliminary studies conducted 
by student researchers tend to be less in visual representation but use other mathematical skills in solving mathematical problems. Z3 subject is a subject with moderate visual representation ability with representation test results in table 3 . Here are the results of the visual representation test and its description of the Z3 subject can be viewed on table 3 below.

Table 3. Z3 Subject Visual Representation Test Results

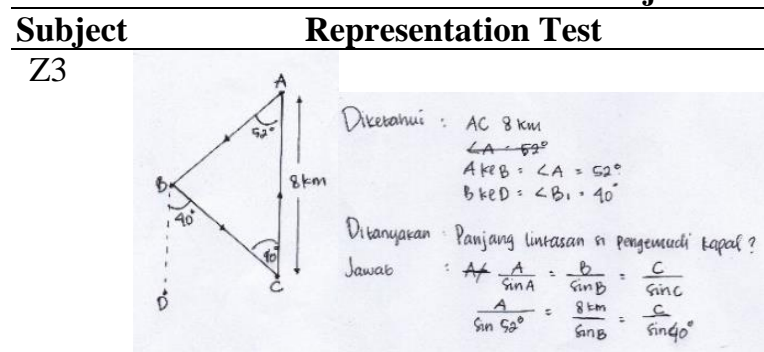

Figure 2. Visual Representation Test of Z3 subject

\section{Description}

Z3 subjects are subjects who have moderate visual representation. The $\mathrm{Z} 3$ subject uses the opposite angle concept to look for another angle, then substitutes all values into the formula mentioned. $\mathrm{Z3}$ subjects have not managed to find another angle to be able to help in the settlement so that the results have not been found.
Based on the results of research on subjects who have moderate visual representation, the results of the analysis of the profile of problem solving abilities for subjects that refer to the stages of Krulik \& Rudnick (1988) obtained include (1) reading, (2) exploring, (3) choosing a strategy, (4) Settlement and (5) Review. Z3 subject is a subject with visual representation ability who is working on problem solving problems that have never been met before on trigonometric material with Krulik \& Rudnick's problem solving analysis attached in table 4 . Here are the results of $\mathrm{Z} 3$ subject work in all stages:

Table 4. Results of Subject Work in All Stages

\begin{tabular}{|c|c|c|}
\hline Stage & Work & Explanation \\
\hline Read & 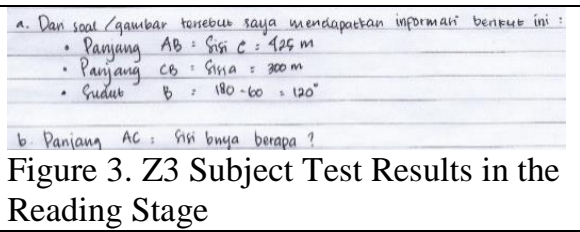 & $\begin{array}{l}\text { The } \mathrm{Z} 3 \text { subject writes "length } \mathrm{A} \text { to } \mathrm{B} \text { " with the } \\
\text { writing "long } \mathrm{AB} \text { ", and "long B to C" with "length } \\
\mathrm{BC} \text { " and writes down the known angles and knows } \\
\text { what is asked. }\end{array}$ \\
\hline Explore & 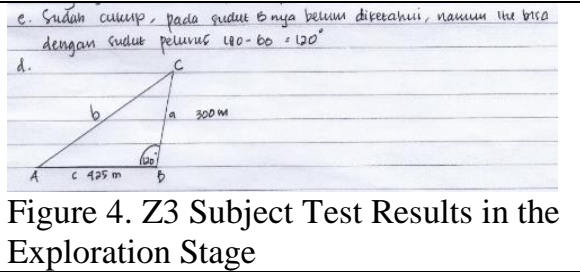 & $\begin{array}{l}\text { the } \mathrm{Z} 3 \text { subject understands and looks for angle B by } \\
\text { using the concept of a straightener angle. The Z3 } \\
\text { subject also shows the schematic type. }\end{array}$ \\
\hline $\begin{array}{l}\text { Select a } \\
\text { strategy }\end{array}$ & $\begin{array}{l}\text { e. Rumus aturan trigonometri yang digunakan yaltu: } \\
\qquad b^{2}=a^{2}+c^{2}-2 a c \sin 6 \\
\text { Figure } 5 . \text { Z3 Subject Test Results in } \\
\text { Selecting a Strategy Stage }\end{array}$ & $\begin{array}{l}\text { The subject writes the formula } \\
\text { " } b^{2}=a^{2}+c^{2}-2 a c \sin B^{n} \text {, the formula is also } \\
\text { almost correct. Z3 subjects have not been able to } \\
\text { explore the problem properly. }\end{array}$ \\
\hline Solve & $\begin{array}{l}f . \begin{aligned} b^{2} & =a^{2}+c^{2}-2 a c \sin 6 \\
& =300^{2}+425^{2}-2 \cdot 300 \cdot 425 \sin 120 \\
& =90 \cdot 000+180.625-255 \cdot 0001 / 2 \sqrt{3} \\
& =270 \cdot 625-125500 \sqrt{3} \\
A c=b & =\sqrt{270 \cdot 625-127 \cdot 500 \sqrt{3}} \\
& =\sqrt{625 \cdot 433-25 \cdot 25 \cdot 209 \sqrt{3}} \\
& =25 \sqrt{433}-25 \cdot 4 \sqrt{17.3 \sqrt{3}} \\
A C & =25 \sqrt{433}-100 \sqrt{5 \sqrt{2}}\end{aligned} \\
\text { Figure 6. Z3 Subject Test Results in } \\
\text { the solving stage }\end{array}$ & $\begin{array}{l}\text { The subject substitutes the known value into the } \\
\text { formula mentioned in the stage of choosing a strategy } \\
\text { correctly. But because the formula used is wrong then } \\
\text { the results are not correct. }\end{array}$ \\
\hline
\end{tabular}


Look Back 9. Yakin, karena yang saya panami pada scal tersebut sepenti itu. Figure 7. Z3 Subject Test Results in the Looking Back Stage
The $\mathrm{Z} 3$ subject wrote a statement that is: "sure, because what I understand in the matter is like that". $\mathrm{Z} 3$ subjects feel confident about their work and are not aware of the formula that is still not right.
Data retrieval is also done through indepth interview methods with Z3 subjects. Written test results data compared with the data from interviews based on Krulik \& Rudnick stages to then obtain valid data from the Z3 subject.

The reading stage of the $\mathrm{Z} 3$ subject explains what is known and asked according to what is in the problem without describing it through the triangular sketch first. In the exploratory phase, the Z3 subject is able to do the stage of exploring the problem well. Based on the indicator type of visual representation consisting of pictorial and schematic presented by Hegarty \& Kozhevnikov (1999), at the exploratory stage shows the type of visual representation of the subject Z3. Z3 subject has a schematic type visual representation. This visual representation is used by the $\mathrm{Z} 3$ subject in solving problems, namely the subject explores the problem and then determines the steps of completion in the next stage. This is as stated by Corter \& Zahner, (2007) that visual representations are useful in solving the problems. Visual representation is useful in solving problems.

The $\mathrm{Z} 3$ subject at the stage of choosing a strategy mentions an incorrect formula is also the use of the symbolic mathematical operations operation that is in the formula is not appropriate in writing it so that the results of the process are less precise. This shows that students are still not aware of the use of formulas in trigonometry because of students' misunderstanding of the use of the formula. This problem is in line with research conducted by Ikram (2016) stating that "the underlying problem in trigonometric methods is because students' long-term memory is not embedded because of the many formulas that students must remember and understand".

At the completion stage, the $\mathrm{Z} 3$ subject states the value of cos in the quadrant. Although the Z3 subject can do calculations well, still the final result of the two subjects' work is still incorrect because there are still deficiencies in the stage of choosing a strategy that is in determining the formula. This shows that the subject has passed a process. This is in line with the statement of Krulik \& Rudnick (1988) which states that problem solving is a process. When the subject is working on the problem given in the form of a problem, at least the subject has gone through a good process and if the subject is more active in practicing working on other problems then it will get good results. Although in this study the subject is still unable to meet the indicators in this stage of completion because they have not been able to produce work that is in accordance with what is determined by the researcher.

While at the stage of reviewing the Z3 subject it still cannot do it well. This is because the subject has not been able to determine the right strategy to solve the problem so that the two stages thereafter have not been resolved properly.

Based on the above analysis can be concluded as follows, from stage 1-5 students can only fulfill mathematical problem solving indicators based on Krulik \& Rudnick stage by $57 \%$ as mentioned in table 5 . Analysis conducted by researchers shows that the $\mathrm{Z3}$ subject is included in students with type schematic visual representation that is describing a diagram / using a sign that shows the spatial relationship between objects in a problem in explaining the solution strategy, or describing the spatial image of the relationship stated in the problem. The researcher found that by using a schematic visual representation that is owned by the Z3 subject can solve the difficult problem given by the researcher. This is in line with what was expressed by Hegarty \& Kozhevnikov that the use of schematic representation was positively correlated with solution success. the use of schematic representation is positively correlated with the success of the solution. 
Table 5. Z3 Subject Problem Solving Ability.

\begin{tabular}{|c|c|}
\hline $\begin{array}{l}\text { Represent } \\
\text { Krulik \& } \\
\text { Rudnick } \\
\text { Stages }\end{array}$ & $\begin{array}{c}\text { Medium (Z3 } \\
\text { Subject) }\end{array}$ \\
\hline Read & $\begin{array}{l}\text { - describe or formulate issues related to the problems used } \begin{array}{l}\text { Both indicators are } \\
\text { met }\end{array} \\
\text { in solving problems. } \\
\text { - rewrite information that is known and asked according to } \\
\text { their own understanding and words }\end{array}$ \\
\hline Explore & $\begin{array}{l}\text { - looking for as much as possible, information that can help } \begin{array}{l}\text { Both indicators are } \\
\text { in solving problems. }\end{array} \\
\text { - create diagrams / graphs / charts / tables. }\end{array}$ \\
\hline Select a Strategy & $\begin{array}{l}\text { - determine the steps to solve the problem, it can be a Indicators are not met } \\
\text { formula selection. }\end{array}$ \\
\hline Solve & $\begin{array}{l}\text { - determine the steps to solve the problem, it can be a Indicators are not met } \\
\text { formula selection. }\end{array}$ \\
\hline Look Back & $\begin{array}{l}\text { review each step of the solution and look for interesting Indicators are not met } \\
\text { variations on the original problem. }\end{array}$ \\
\hline Conclusion & $\begin{array}{l}\text { Of the five problem solving stages of Krulik and Rudnick, the ability to solve } \\
\text { mathematical problems of } \mathrm{Z} 3 \text { subjects is } 57 \% \text {. }\end{array}$ \\
\hline
\end{tabular}

\section{CONCLUSION}

Based on the results of research that has been conducted on subjects with moderate visual representation, the conclusion is that students still have not been able to solve mathematical problems given very well. Of the five stages of problem solving Krulik \& Rudnick can only complete two initial stages but the next three stages in solving the problem there is one stage of calculation that is less precise so that the next calculation is an error.

Subjects have a schematic type of visual representation that can show the relationship between object images in explaining the settlement strategy. This schematic type of

\section{REFERENCES}

Agustinova, D. E. (2015). Memahami Metode Penelitian Kualitatif. Yogyakarta: Calpulis.

Carson, J. (2007). A Problem With Problem Solving: Teaching Thinking Without Teaching Knowledge. Problem Solving, 8.

Corter, J. E., \& Zahner, D. C. (2007). Use Of External Visual Representations In Probability Problem Solving4, 29.

Gordah, E. K., \& Fadillah, S. (2014). Pengaruh Penggunaan Bahan Ajar Kalkulus visual representation is very helpful for the subject in determining the settlement strategy so that it is easier to solve problems.

Based on the conclusions of the results of this study, the following suggestions can be put forward: this study has not analyzed students who have schematic type visual representation from the beginning of the determination of the research subject so that further research is expected to classify based on the type of visual representation at the beginning of determining the subject so that the results of the study can be more indepth.

Diferensial Berbasis Pendekatan Open Ended Terhadap Kemampuan Representasi Matematis Mahasiswa. Jurnal Pendidikan Dan Kebudayaan, 20(3), 340. Https://Doi.Org/10.24832/Jpnk.V20i3.148 Hegarty, M., \& Kozhevnikov, M. (1999). Types Of Visual-Spatial Representations And Mathematical Problem Solving, 6. Hudiono, B. (2010). Peran Pembelajaran Diskursus Multi Representasi Terhadap 
Pengembangan Kemampuan Matematika Dan Daya Representasi Pada Siswa SLTP, 10.

Ikram, M. (2016). Eksplorasi Penalaran Siswa

Dalam Pemecahan Masalah Trigonometri Ditinjau Dari Kemampuan Berpikir Logis Pada Siswa Kelas XII-IPA, 1(1), 6.

Krulik, S., \& Rudnick, J. A. (1988). Problem Solving: A Handbook For Elementary School Teachers. Boston: Allyn And Bacon.

Listiyana, F. (2012). Analisis Kesulitan Siswa Dalam Menyelesaikan Soal RumusRumus Segitiga Pada Materi Trigonometri Kelas X SMAN 1 Cawas Kabupaten Klaten, 18.

Mulyati, M. (2016). Peningkatan Kemampuan Pemahaman Dan Representasi Matematis Siswa Sma Melalui Strategi PreviewQuestion-Read-Reflect-Recite-Review.
Jurnal Analisa, 2(3), 36. Https://Doi.Org $/ 10.15575 / \mathrm{Ja} . V 2 \mathrm{i} 3.1223$

Nawi, M. (2012). Pengaruh Strategi Pembelajaran Dan Kemampuan Penalaran Formal Terhadap Hasil Belajar Matematika Siswa Sekolah Menengah Atas (Swasta) Al Ulum Medan, 9, 16.

Rezeki, S. (2017). Meningkatkan Kemampuan Representasi Matematis Siswa Melalui Penerapan Model Pembelajaran Novick, 1(3), 11.

Rosanti, A. S., Rizal, M., \& Ismaimuza, D. (2014). Pengetahuan Siswa SMP Kelas VIII Dalam Memecahkan Masalah Matematika Non Geometri Berdasarkan Level 2 Perkembangan Berpikir Van Hiele, 9.

Sabirin, M. (2014). Representasi Dalam Pembelajaran Matematika. Jurnal Pendidikan Matematika, 1(2), 33. Https://Doi.Org/10.18592/Jpm.V1i2.49 